\title{
The enzymatic hydrolysates from deer sinew promote MC3T3-E1 cell proliferation and extracellular matrix synthesis by regulating multiple functional genes
}

Zhenwei Zhou', Daqing Zhao', Pengcheng Zhang ${ }^{2}$, Mei Zhang ${ }^{3}$, Xiangyang Leng ${ }^{2^{*}}$ and Baojin Yao ${ }^{1^{*}}$ (D)

\begin{abstract}
Background: Deer Sinew serves as a medicinal food, and has been used for treating skeletal diseases, especially bone diseases in a long history. Thus, it could become an alternative option for the prevention and therapeutic remedy of bone-related diseases. In our previous study, we established an optimal extraction process of the enzymatic hydrolysates from Chinese Sika deer sinews (DSEH), and we demonstrated that DSEH significantly promoted the proliferation of MC3T3-E1 cells (an osteoblast-like cell line) with a certain dose-effect relationship. However, the precise molecular mechanism of deer sinew in regulating bone strength is still largely unknown. The aim of this study was to explore the underlying molecular mechanism of DSEH on MC3T3-E1 cells proliferation and extracellular matrix synthesis.
\end{abstract}

Methods: Preparation and quality control were performed as previously described. The effect of DSEH at different administrated concentrations on cell proliferation was measured using both CCK-8 and MTT assays, and the capacity of DSEH on extracellular matrix synthesis was detected by Alizarin red staining and quantification. The gene expression pattern change of MC3T3-E1 cells under the treatment of DSEH was investigated by RNA-seq analysis accompanied with validation methods.

Results: We demonstrated that DSEH promoted MC3T3-E1 cell proliferation and extracellular matrix synthesis by regulating multiple functional genes. DSEH significantly increased the expression levels of genes that promoted cell proliferation such as Gstp1, Timp1, Serpine1, Cyr61, Crlf1, Thbs1, Ctgf, P4ha2, Sod3 and Nqo1. However, DSEH significantly decreased the expression levels of genes that inhibited cell proliferation such as Mt1, Cdc20, Gas1, Nrp2, Cmtm3, Dlk2, Sema3a, Rbm25 and Hspb6. Furthermore, DSEH mildly increased the expression levels of osteoblast gene markers.

(Continued on next page)

\footnotetext{
*Correspondence: leng_xiangyang@163.com; baojin.yao1983@yahoo.com

${ }^{2}$ The Affiliated Hospital of Changchun University of Chinese Medicine, Changchun 130117, China

'Jilin Ginseng Academy, Changchun University of Chinese Medicine, Changchun 130117, China

Full list of author information is available at the end of the article
}

(C) The Author(s). 2021 Open Access This article is licensed under a Creative Commons Attribution 4.0 International License, which permits use, sharing, adaptation, distribution and reproduction in any medium or format, as long as you give appropriate credit to the original author(s) and the source, provide a link to the Creative Commons licence, and indicate if changes were made. The images or other third party material in this article are included in the article's Creative Commons. licence, unless indicated otherwise in a credit line to the material. If material is not included in the article's Creative Commons licence and your intended use is not permitted by statutory regulation or exceeds the permitted use, you will need to obtain permission directly from the copyright holder. To view a copy of this licence, visit http://creativecommons.org/licenses/by/4.0/ The Creative Commons Public Domain Dedication waiver (http://creativecommons.org/publicdomain/zero/1.0/) applies to the data made available in this article, unless otherwise stated in a credit line to the data. 


\begin{abstract}
(Continued from previous page)
Conclusions: Our findings suggest that DSEH facilitate MC3T3-E1 cell proliferation and extracellular matrix synthesis to consolidate bone formation and stability, but prevent MC3T3-E1 cells from oxidative stress-induced damage, apoptosis and further differentiation. These findings deepened the current understanding of DSEH on regulating bone development, and provided theoretical support for the discovery of optional prevention and treatment for bone-related diseases.
\end{abstract}

Keywords: Deer sinew, Enzymatic hydrolysates, MC3T3-E1 cells, RNA sequencing, Differentially expressed genes, Molecular mechanism

\section{Background}

Deer Sinew, a precious animal production, has been widely used in traditional Chinese remedies to support bone health for over 20 centuries. According to the theory of traditional Chinese medicine, Deer sinews are considered to be more effective than cattle sinews in nourishing kidney yang (shen yang) and strengthening bones and tendons [1]. Several studies have shown that deer sinew extract could prevent bone loss in osteoporosis model and reduce the injury risk of musculoskeletal system. By using an ovariectomized rat model of osteoporosis, the researchers demonstrated that deer sinew extract could significantly increase bone mineral density and serum hydroxyproline, and improve the histomorphometric parameters and mechanical indicators of bone [2]. Consistent with the above results, according to the investigation of a retinoic acid-induced rat model of osteoporosis, the researchers demonstrated that deer sinew extract could increase bone mineral density and bone weight [3]. In a clinical investigation of the effect of deer sinew supplementation on the exercise performance and risk training injury of a population of athletes, the researchers demonstrated that deer sinew extract could improve exercise performance and reduce the injury risk of musculoskeletal system [4]. Furthermore, several studies have also shown that deer sinew extract has potential anti-inflammatory effects [5-7]. Sinews, also known as tendons, are fibrous connective tissues that localize between bones and muscles [8]. The major components of sinews are collagens, especially type I collagen, which account for 65 to $80 \%$ of the dry mass [9]. Meanwhile, collagens including types I, III and V are the major extracellular matrices in bone, and type I collagen accounts for about $95 \%$ of the total collagen components present in bone and approximately $80 \%$ of the entire proteins of bone. Those collagens thus play pivotal roles in maintaining bone strength and further prevent bone fragility related diseases, such as osteogenesis imperfecta and osteoporosis [10]. However, the precise molecular mechanism of deer sinew in regulating bone strength is still largely unknown.

In recent years, high-throughput sequencing technology has led rapid increase in understanding the physiological and pathological mRNA dynamics, which further influence the protein expression that involved in the growth, development and related functions of cells as well as organ systems [11]. It is particularly noteworthy that RNA sequencing (RNA-seq) has also been widely used in skeletal biology research to solve tough problems regarding the development and disease control of skeletal tissues, including bone, cartilage, tendon and ligament [12]. During bone formation and repair, osteoblasts serve as bone-forming cells that are required for the synthesis of bone matrix, including collagen proteins (mainly type I collagen), noncollagen proteins (osteocalcin, osteonectin, bone sialoprotein II and osteopontin), and proteoglycans (decorin and biglycan) $[13,14]$.

In our previous study, we established an optimal extraction process of the enzymatic hydrolysates from Chinese Sika deer sinews (DSEH). The yield of DSEH was $58.56 \%$, and the protein concentration was $48.4 \%$. Cell proliferation assay showed that DSEH significantly promoted the proliferation of MC3T3-E1 cells (an osteoblast-like cell line) with a certain dose-effect relationship, and the proliferative effect was most significant at an administration concentration of $8 \mathrm{mg} / \mathrm{ml} \mathrm{[15].}$ Therefore, in the present study, we performed RNA-seq analysis accompanied with validation methods to explore the underlying molecular mechanism of DSEH on MC3T3-E1 cells via deeply dissecting the gene expression patterns under DSEH treatment. We demonstrated that DSEH promoted MC3T3-E1 cell proliferation and extracellular matrix synthesis by regulating multiple functional genes. DSEH significantly increased the expression levels of genes that promoted cell proliferation such as Gstp1, Timp1, Serpine1, Cyr61, Crlf1, Thbs1, Ctgf, P4ha2, Sod3 and Nqo1. However, DSEH significantly decreased the expression levels of genes that inhibited cell proliferation such as Mt1, Cdc20, Gas1, Nrp2, Cmtm3, Dlk2, Sema3a, Rbm25 and Hspb6. Furthermore, DSEH mildly increased the expression levels of osteoblast gene markers. Our findings deepened the current understanding of DSEH on regulating bone development, and provided theoretical support for the discovery of optional prevention and treatment for bonerelated diseases. 


\section{Methods}

\section{DSEH treatment and cell proliferation assay}

Deer sinews were purchased from the Shuangyang deer farm in Changchun, China. The preparation of the enzymatic hydrolysates from Chinese Sika deer sinews (DSEH) was carried out as previously described [15]. All procedures were submitted and approved by the ethics committee of Changchun University of Chinese Medicine in accordance with the guidelines of the ethical protocol (No. ccucm-2017-0015). Primary osteoblasts from individual calvaria of newborn C57BL/6 mice $(n=$ 6) were isolated according to the previous protocol [16]. Primary osteoblasts and MC3T3-E1 cells (ATCC, USA) were inoculated into a 96-well cell culture plate (Thermo, USA) at a cell density of $5 \times 10^{3}$ cells/well, respectively, and incubated in a humidified incubator (Thermo, USA) containing $5 \% \mathrm{CO}_{2}$ at $37^{\circ} \mathrm{C}$ for $12 \mathrm{~h}$. The effects of DSEH at different administrated concentrations $(0,2 \mathrm{mg} / \mathrm{ml}, 4 \mathrm{mg} / \mathrm{ml}, 6 \mathrm{mg} / \mathrm{ml}, 8 \mathrm{mg} / \mathrm{ml}$ and 10 $\mathrm{mg} / \mathrm{ml}$ ) on cell proliferation were measured using a CCK-8 assay kit (Sigma, USA) and a MTT assay kit (Sigma, USA) according to the manufacturers' protocols.

\section{Alizarin red staining and quantification}

Primary osteoblasts and MC3T3-E1 cells were inoculated into a 24-well cell culture plate at a cell density of $2 \times 10^{4}$ cells/well, and incubated in a humidified incubator (Thermo, USA) containing $5 \% \mathrm{CO}_{2}$ at $37^{\circ} \mathrm{C}$ for $24 \mathrm{~h}$. The cells were either treated by DSEH at an optimum concentration based on the result of the cell proliferation assay or treated with plain culture medium (Thermo, USA), and incubated for $24 \mathrm{~h}$. All culture mediums were removed, and cells were washed with phosphate-buffered saline buffer (Thermo, USA). Cell fixation was performed at room temperature by incubating with $4 \%$ paraformaldehyde for $15 \mathrm{~min}$. After washing with Millipore purified water for three times, the fixed cells were stained with $1 \%$ Alizarin red S staining solution (Solarbio, China) for $0.5 \mathrm{~h}$ at room temperature, and washed with purified water for three times. Images were taken with an optical microscope (Olympus, Japan) accompanied with a digital camera. Quantitative analysis was carried out by dissolving the stained cells with $10 \%$ acetic acid (Thermo, USA) at room temperature for 0.5 $\mathrm{h}$ with gentle shaking, followed by vortexing, heating, centrifuging and neutralizing by ammonium hydroxide, and quantified using a plate reader (Life science, USA) at an optical density (OD) of $405 \mathrm{~nm}$ [17].

\section{RNA purification and quality control}

MC3T3-E1 cells were inoculated into a 6-well cell culture plate at a cell density of $1 \times 10^{6}$ cells/well, and incubated in a humidified incubator (Thermo, USA) containing $5 \% \mathrm{CO}_{2}$ at $37^{\circ} \mathrm{C}$ for $12 \mathrm{~h}$. The cells were either treated with DSEH at an optimum concentration based on the result of the cell proliferation assay or treated with plain culture medium (Thermo, USA). All culture mediums were removed, and cells were gently rinsed with precooled phosphate-buffered saline buffer (Thermo, USA). Total RNA from experiments in triplicate was isolated with TRIzol reagent (Invitrogen, USA) according to the manufacturer's instructions. The total RNA was qualified and quantified based on the RNA integrity number (RIN) measured by an Agilent Bioanalyzer 2100 (Agilent Technologies, USA) following the instrument's protocols.

\section{Library construction and sequencing}

The RNA-seq libraries were generated using a TruSeq Stranded mRNA kit (Illumina, USA) in accordance with the company's recommendations. Briefly, the messenger RNA containing poly (A) was purified from the total RNA using a magnetic poly ( $\mathrm{T}$ ) beads. Messenger RNA was broke into short fragments with a fragmentation buffer. Double stranded cDNA was synthesized by random hexamer primers, following by purification, repair and sequencing adapter ligation, and amplified by polymerase chain reaction to generate the libraries. The libraries were sequenced by performing high-throughput sequencing via the Illumina HiSeq 2500 platform with a paired-end read length of $150 \mathrm{bp}$ (Illumina, USA).

\section{Sequencing data analysis}

After illumine sequencing, the image data was transformed via base calling into raw data in FASTQ format. The raw data were processed using Perl scripts to generate clean reads by removing the low-quality reads and adapter sequences, following by Q30 evaluation and GC content calculation. The data sets were submitted into the NCBI Sequence Read Archive (SRA) database with an accession number PRJNA612675. Subsequently, the clean reads were aligned with the mouse (Mus musculus) reference genome using the HISAT program [18]. The gene expression levels of each transcript were estimated according to the FPKM algorithm [19]. The BLAST program was used to perform annotation against the NonRedundant (NR) and Swiss-Prot protein databases [20]. The differential expression between the DSEH treated group and untreated group were analyzed by the DEGseq program [21]. Differentially expressed genes (DEGs) were identified using the following criteria: $\log 2$ fold change $\geq 1$ or $\leq-1$ and with a $p$ value $\leq 0.001$.

\section{Enrichment analysis}

The enrichment analysis of Gene ontology (GO) and Kyoto Encyclopedia of Genes and Genomes (KEGG) was conducted by $\mathrm{R}$ function phyper to determine the biological functions and signaling pathways of those 
identified DEGs. The significance of enriched functional clusters and signaling pathways were determined based on the adjusted $p$ value ( $\mathrm{Q}$ value) of less than 0.05 , which was calculated according to the Hypergeometric test and Bonferroni correction [22].

\section{Quantitative real-time PCR (qRT-PCR) verification}

The RNA-seq results were further verified through examining the expression levels of DEGs by qRT-PCR assay. Briefly, total RNA was extracted using the TRIzol reagent (Invitrogen, USA) in accordance with the manufacturer's protocols. Reverse-transcribed cDNA was synthesized using the iScript cDNA Synthesis kit (Bio-Rad, USA), following by qRT-PCR detection under standard amplification condition using a generic SYBR_ Green Supermix kit (Bio-Rad, USA) on a CFX Connect RealTime PCR Detection System (Bio-Rad, USA). The gene of mouse glyceraldehyde 3-phosphate dehydrogenase (Gapdh) was selected as the internal reference gene. The normalized expression of validated genes was calculated based on the $2^{-\triangle \Delta C T}$ method [23].

\section{Effects of DSEH on osteoporotic model caused by} hydrogen peroxide $\left(\mathrm{H}_{2} \mathrm{O}_{2}\right)$-induced oxidative injury Effects of DSEH on MC3T3-E1 cells under hydrogen peroxide $\left(\mathrm{H}_{2} \mathrm{O}_{2}\right)$-induced oxidative injury were evaluated to further validate the regulatory function of DSEH on osteoblasts [24]. Briefly, MC3T3-E1 cells were either treated with $500 \mu \mathrm{M} \mathrm{H} \mathrm{H}_{2} \mathrm{O}_{2}$ for $6 \mathrm{~h}\left(\mathrm{H}_{2} \mathrm{O}_{2}\right.$ group), or treated with $500 \mu \mathrm{M} \mathrm{H}_{2} \mathrm{O}_{2}$ for $6 \mathrm{~h}$ followed by the addition of $8 \mathrm{mg} / \mathrm{ml}$ DSEH $\left(\mathrm{H}_{2} \mathrm{O}_{2}+\mathrm{DSEH}\right.$ group), untreated MC3T3-E1 cells serve as a negative control (Blank group). Cells were double stained with propidium iodide (PI) and Annexin V-FITC using a BD Apoptosis Detection Kit (Thermo, USA), and analyzed by a FlowSight ${ }^{\circ}$ Imaging Flow Cytometer (Merck Millipore, USA). Analysis of cell apoptosis was performed using the IDEAS Application V6.1 software (Amnis, USA).

\section{Results}

DSEH promoted MC3T3-E1 cell and primary osteoblast proliferation in a dose-dependent manner

We first investigated the effects of DSEH on the cell proliferation of MC3T3-E1 cells and primary osteoblasts. The results of CCK-8 assay showed that DSEH promoted the proliferation of MC3T3-E1 cells and primary osteoblasts in a dose-dependent manner, as shown in Fig. 1. Compared with the untreated group $(0 \mathrm{mg} / \mathrm{ml})$, the viabilities of both cells were significantly increased under the DSEH treatment at progressively increasing concentrations. Meanwhile, the results of MTT assay also showed similar results as those of CCK- 8 assy. Since DSEH treatments at the concentration of $8 \mathrm{mg} / \mathrm{ml}$ had the highest cell viability, thus, in the following experiments, the concentration of DSEH treatment was selected as $8 \mathrm{mg} / \mathrm{ml}$.




DSEH enhanced MC3T3-E1 cell extracellular matrix synthesis in a time-dependent manner

In order to investigate the effects of DSEH on osteoblast extracellular matrix synthesis, we performed Alizarin red staining and quantification at different time points as follows, $1 \mathrm{~d}, 3 \mathrm{~d}, 5 \mathrm{~d}, 7 \mathrm{~d}, 11 \mathrm{~d}$ and $13 \mathrm{~d}$. As shown in Fig. 2, DSEH significantly enhanced extracellular matrix synthesis of MC3T3-E1 cells at day 1 and day 3 with a similar pattern, but inhibit extracellular matrix synthesis of MC3T3-E1 cells from day 7 to day 13. However, DSEH showed no significant effects on extracellular matrix synthesis of primary osteoblasts.

\section{Gene expression analysis of MC3T3-E1 cells with or} without DSEH treatment was performed by RNA sequencing, genome mapping, and transcript annotation To explore the molecular mechanism underlying the effects of DSEH on MC3T3-E1 cells, we performed RNAseq analysis on MC3T3-E1 cells with or without DSEH treatment. As shown in Table 1, after Illumina sequencing and data processing, 62,258,284 and 42,159,210 clean reads were obtained from MC3T3-E1 cells treated with plain medium (Blank group) and those treated with DSEH (DSEH group), respectively. The quality assessment showed that the Q30 percentages were more than $92 \%$, and the GC content percentages were approximately 52\%. For the Blank and DSEH-treated samples, $59,578,848$ and $40,340,992$ clean reads were mapped to the mouse genome, respectively. In total, 13,962 out of 14,295 (Blank group), and 14,057 out of 14,373 (DSEH group) transcripts were annotated by searching against the Non-Redundant (NR) NCBI protein database and Swiss-Prot protein database, respectively.

A series of DEGs were identified in MC3T3-E1 cells with or without DSEH treatment

Differential expression analysis was carried out to discover DEGs significantly changed under DSEH

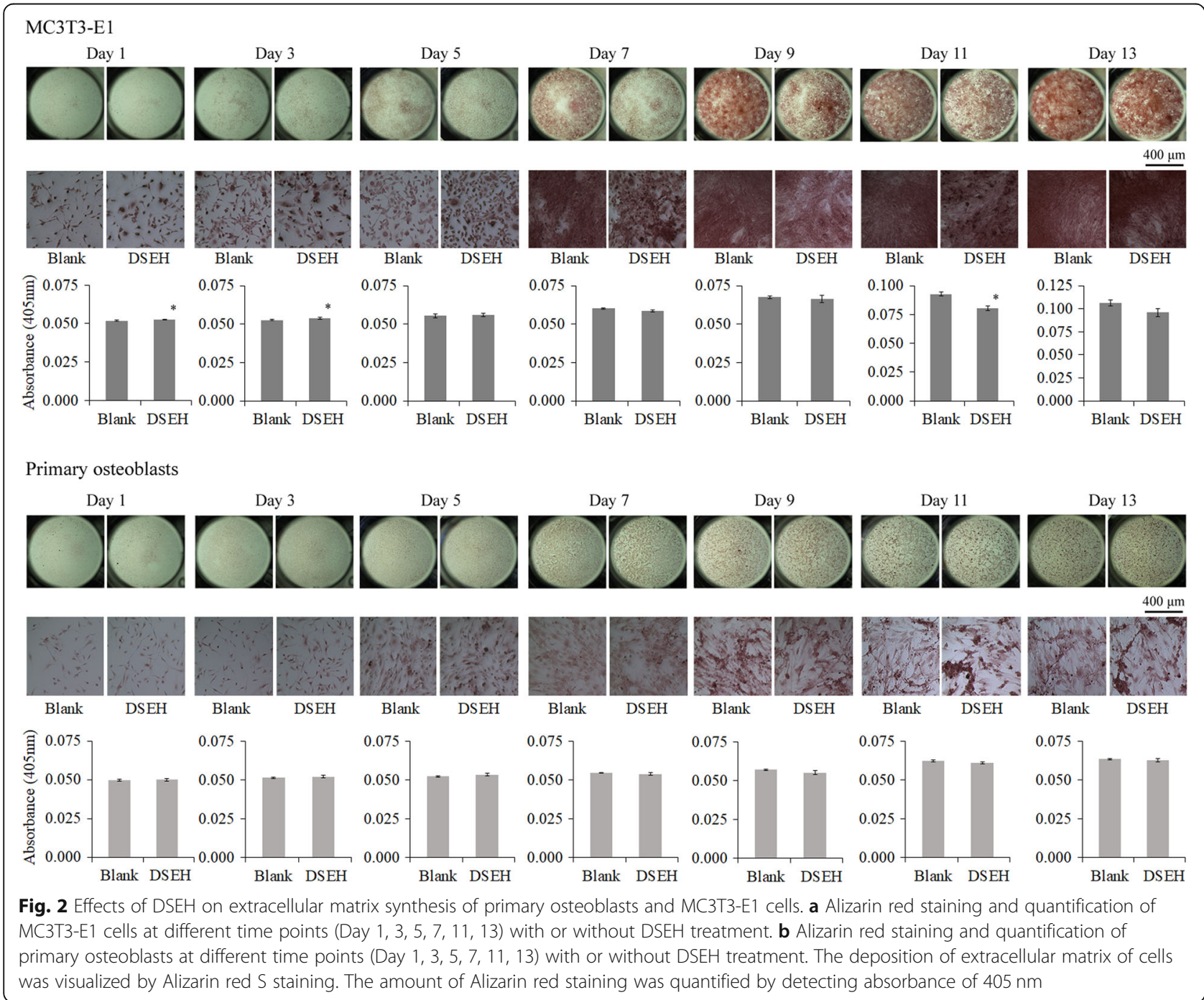


Table 1 Statistic overview of sequencing and mapping results

\begin{tabular}{lll}
\hline Statistics & Blank group & DSEH group \\
\hline Clean reads & $62,258,284$ & $42,159,210$ \\
Q30 percentage & 92.44 & 92.56 \\
GC percentage & 51.77 & 52.05 \\
Total mapped reads & $59,578,848$ & $40,340,992$ \\
Total transcripts & 14,295 & 14,373 \\
Known transcripts & 13,962 & 14,057 \\
\hline
\end{tabular}

treatment. As shown in Table 2, in total, 841 genes with significant differences in the expression levels between DSEH group and Blank group were identified. Among those identified DEGs, 494 DEGs were significantly upregulated, and 347 genes were significantly downregulated (DSEH group vs. Blank group). The top 20 upregulated DEGs mainly consisted of glutathione Stransferase P1 (Gstp1), metalloproteinase inhibitor 1 (Timp1), plasminogen activator inhibitor 1 (Serpine1), protein CYR61 (Cyr61), H-2 class I histocompatibility antigen $\mathrm{D}-\mathrm{B}$ alpha chain $(\mathrm{H} 2 \mathrm{~d} 1)$ and connective tissue growth factor (Ctgf), etc., as shown in Table 3, whereas the top 20 down-regulated DEGs mainly consisted of metallothionein-1 (Mt1), non-histone chromosomal protein HMG-17 (Hmgn2), prolactin-2C2 (Pr12c2), cell division cycle protein 20 homolog (Cdc20), prolactin-2C3 (Prl2c3) and transmembrane glycoprotein NMB (Gpnmb), etc., as shown in Table 4.

\section{DEGs were classified into a variety of functional categories by functional enrichment analysis}

GO enrichment analysis was performed to specify the distribution of these identified DEGs in cellular location, function and physiological processes. According to the functional enrichment analysis of DEGs, the identified DEGs were classified into the following GO categories: cellular component, molecular function and biological process, as shown in Fig. 3. Cellular component classification showed that most of the DEGs were located in the regions of extracellular matrix, intracellular part and organelle. Molecular function classification showed that the dominant functions of these DEGs were involved in binding activities, such as protein binding and ion binding. Biological process classification showed that these DEGs mainly participated in the biological processes including regulation of metabolic process, single-

Table 2 Statistic summary of DEGs (DSEH group vs. Blank group)

\begin{tabular}{ll}
\hline Statistics & Number \\
\hline Differentially expressed mRNA & 841 \\
Upregulated mRNAs & 494 \\
Downregulated mRNAs & 347 \\
\hline
\end{tabular}

multicellular organism process and developmental process.

\section{DEGs were mapped into multiple signaling pathways by pathway enrichment analysis}

KEGG enrichment analysis was carried out to uncover the related signaling pathways by searching the identified DEGs against the KEGG database. As shown in Fig. 4, the DEGs were mainly mapped to the following nine signaling pathways, including thyroid hormone signaling pathway, regulation of actin cytoskeleton, PI3K-Akt signaling pathway, FoxO signaling pathway, focal adhesion, ECM-receptor interaction, cAMP signaling pathway and axon guidance.

\section{DSEH increased the expression levels of genes positively regulating the proliferation of MC3T3-E1 cells}

Next, we screened the DEGs involved in positively regulating cell proliferation to further dissect the molecular mechanisms of DSEH on regulating MC3T3-E1 cells. Among the identified DEGs, there were 10 up-regulated DEGs, including glutathione S-transferase P1 (Gstp1), metalloproteinase inhibitor 1 (Timp1), metalloproteinase inhibitor 1 (Serpine1), protein CYR61 (Cyr61), cytokine receptor-like factor 1 (Crlf1), thrombospondin-1 (Thbs1), connective tissue growth factor (Ctgf), prolyl 4hydroxylase subunit alpha-2 (P4ha2), extracellular superoxide dismutase (Sod3) and $\mathrm{NAD}(\mathrm{P}) \mathrm{H}$ dehydrogenase [quinone] 1 (Nqo1), which positively regulated the proliferation of osteoblasts, as shown in Table 5.

DSEH decreased the expression levels of genes negatively regulating the proliferation of MC3T3-E1 cells

Then, we screened the DEGs involved in negatively regulating the proliferation of MC3T3-E1 cells. In consistent with the above results, among the identified DEGs, there were 9 down-regulated DEGs, including metallothionein-1 (Mt1), cell division cycle protein 20 homolog (Cdc20), growth arrest-specific protein 1 (Gas1), neuropilin-2 (Nrp2), CKLF-like MARVEL transmembrane domain-containing protein 3 (Cmtm3), semaphorin-3A (Sema3a), protein delta homolog 2 (Dlk2), RNA-binding protein 25 (Rbm25) and heat shock protein beta-6 (Hspb6), which negatively regulated the proliferation of osteoblasts, as shown in Table 6.

DSEH mildly increased the expression levels of osteoblast markers in MC3T3-E1 cells

Finally, we analyzed the expression levels of osteoblast markers under DSEH treatment in order to have a deeper recognition regarding the effects of DSEH on MC3T3-E1 cells. The results were consistent with our above findings that DSEH mildly increased the expression levels of multiple osteoblast marker genes including 
Table 3 List of the top 20 up-regulated DEGs (DSEH group vs. Blank group)

\begin{tabular}{|c|c|c|c|c|}
\hline Gene name & Blank (FPKM) & DSEH (FPKM) & $\log _{2}$ fold change (DSEH /Blank) & $P$ value \\
\hline Glutathione S-transferase P1 (Gstp1) & 367.61 & 855.07 & 1.22 & $2.30 \mathrm{E}-308$ \\
\hline Metalloproteinase inhibitor 1 (Timp1) & 286.17 & 601.03 & 1.07 & 2.54E-223 \\
\hline Plasminogen activator inhibitor 1 (Serpine1) & 131.49 & 550.47 & 2.07 & 0 \\
\hline Protein CYR61 (Cyr61) & 153.48 & 444.08 & 1.53 & 0 \\
\hline $\mathrm{H}-2$ class I histocompatibility antigen, D-B alpha chain ( $\mathrm{H} 2 \mathrm{~d} 1)$ & 173.13 & 359.46 & 1.05 & 2.90E-274 \\
\hline Connective tissue growth factor (Ctgf) & 28.09 & 357.75 & 3.67 & 0 \\
\hline Radiation-inducible immediate-early gene IEX-1 (ler3) & 76.23 & 338.48 & 2.15 & 0 \\
\hline Cytokine receptor-like factor 1 (Crlf1) & 75.46 & 270.42 & 1.84 & 0 \\
\hline Thrombospondin-1 (Thbs1) & 94.94 & 248.54 & 1.39 & 0 \\
\hline Metalloproteinase inhibitor 3 (Timp3) & 69.64 & 214.57 & 1.62 & 0 \\
\hline Thioredoxin reductase 1, cytoplasmic (Txnrd1) & 98.89 & 206.75 & 1.06 & 0 \\
\hline Host cell factor $\mathrm{C} 1$ regulator 1 (Hcfc1r1) & 80.00 & 206.17 & 1.37 & 8.01E-166 \\
\hline Cysteine and glycine-rich protein 2 (Csrp2) & 91.15 & 201.85 & 1.15 & $1.22 \mathrm{E}-83$ \\
\hline Serine protease HTRA1 (Htra1) & 98.34 & 200.55 & 1.03 & $8.28 \mathrm{E}-177$ \\
\hline Rho-related GTP-binding protein RhoB (Rhob) & 78.30 & 199.78 & 1.35 & $3.74 \mathrm{E}-304$ \\
\hline Thioredoxin-interacting protein (Txnip) & 26.89 & 175.95 & 2.71 & 0 \\
\hline Heme transporter HRG1 (Slc48a1) & 67.54 & 157.59 & 1.22 & $1.89 \mathrm{E}-230$ \\
\hline Annexin A6 (Anxa6) & 62.46 & 148.03 & 1.24 & $9.92 \mathrm{E}-235$ \\
\hline Flavin reductase (NADPH)(Blvrb) & 47.91 & 142.93 & 1.58 & 9.87E-95 \\
\hline Proline-rich protein 13 (Prr13) & 47.48 & 135.82 & 1.52 & 1.47E-117 \\
\hline
\end{tabular}

osteopontin (Spp1), collagen alpha-1(I) chain (Col1a1), fibronectin (Fn1), cyclic AMP-dependent transcription factor ATF-4 (Atf4), bone marrow stromal antigen 2 (Bst2) and bone morphogenetic protein 1 (Bmp1), etc., as shown in Table 7.

The accuracy of RNA-seq results was further consolidated by qRT-PCR assay

To further verify and consolidate the accuracy of the RNA-seq data, 12 DEGs including 6 up-regulated genes (Gstp1, Timp1, Serpine1, Cyr61, Crlf1 and Thbs1) and 6 down-regulated genes (Mt1, Cdc20, Gas1, Nrp2, Cmtm3 and Dlk2) were chosen to verify the accuracy of RNAseq results by analyzing their expression levels using qRT-PCR assay. Gene specific primer sequences were shown in Table 8 . The relative mRNA expression levels were presented in Fig. 5. The results showed that the qRT-PCR assay obtained consistent results with those obtained by RNA-seq analysis.

DSEH inhibited MC3T3-E1 cell apoptosis caused by $\mathrm{H}_{2} \mathrm{O}_{2}-$ induced oxidative injury

In order to confirm the results obtained by cell proliferation assay, Alizarin red staining and RNA-seq analysis, effects of DSEH on MC3T3-E1 cells under $\mathrm{H}_{2} \mathrm{O}_{2}$-induced oxidative injury were analyzed using Annexin V/ PI staining and flow cytometry following $24 \mathrm{~h}$ of incubation with DSEH. As shown in Fig. 6, compared with the negative control group (Blank), the percentage of apoptotic cells (R4: early apoptotic cells; R5: late apoptotic cells) were increased under $\mathrm{H}_{2} \mathrm{O}_{2}$ induction $\left(\mathrm{H}_{2} \mathrm{O}_{2}\right)$. However, DSEH treatment $\left(\mathrm{H}_{2} \mathrm{O}_{2}+\mathrm{DSEH}\right)$ decreased the percentage of apoptotic cells, especially the late apoptotic cells.

\section{Discussion}

Sinew shares a series of types of collagen components with bone, including type I, III and V collagens, of which type I collagen is expressed in the whole process of bone growth and development, and type III collagen play pivotal role in regulating bone regeneration during the process of bone repair [25]. Deer Sinew serves as a medicinal food, and has been used for treating skeletal diseases, especially bone diseases in a long history. Thus, it could become an alternative option for the prevention and therapeutic remedy of bone-related diseases. However, the exact regulation mechanism remains to be elucidated. In the present study, the results of CCK- 8 assay showed that DSEH promoted the proliferation of both MC3T3-E1 cells and primary osteoblasts in a dosedependent manner. Based on the analysis of Alizarin red staining and quantification, DSEH significantly enhanced extracellular matrix synthesis of MC3T3-E1 cells at day 1 and day 3 with a similar pattern, but inhibit 
Table 4 List of the top 20 down-regulated DEGs (DSEH group vs. Blank group)

\begin{tabular}{|c|c|c|c|c|}
\hline Gene name & $\begin{array}{l}\text { Blank } \\
\text { (FPKM) }\end{array}$ & $\begin{array}{l}\text { DSEH } \\
\text { (FPKM) }\end{array}$ & $\begin{array}{l}\log _{2} \text { fold change (DSEH } \\
\text { /Blank) }\end{array}$ & $P$ value \\
\hline Metallothionein-1 (Mt1) & 419.48 & 188.65 & -1.15 & $\begin{array}{l}6.40 \mathrm{E}- \\
107\end{array}$ \\
\hline Non-histone chromosomal protein HMG-17 (Hmgn2) & 310.59 & 145.14 & -1.10 & $\begin{array}{l}4.58 \mathrm{E}- \\
176\end{array}$ \\
\hline Prolactin-2C2 (Prl2c2) & 302.57 & 105.30 & -1.52 & $\begin{array}{l}9.84 \mathrm{E}- \\
167\end{array}$ \\
\hline Cell division cycle protein 20 homolog (Cdc20) & 118.90 & 57.15 & -1.06 & 3.10E-94 \\
\hline Prolactin-2C3 (Prl2c3) & 166.68 & 55.41 & -1.59 & $\begin{array}{l}1.69 \mathrm{E}- \\
109\end{array}$ \\
\hline Transmembrane glycoprotein NMB (Gpnmb) & 76.68 & 30.90 & -1.31 & $\begin{array}{l}1.28 \mathrm{E}- \\
184\end{array}$ \\
\hline Neuropilin-2 (Nrp2) & 45.13 & 22.36 & -1.01 & $\begin{array}{l}2.48 \mathrm{E}- \\
107\end{array}$ \\
\hline Muscleblind-like protein 1 (Mbnl1) & 58.40 & 19.94 & -1.55 & $\begin{array}{l}6.30 \mathrm{E}- \\
240\end{array}$ \\
\hline Growth arrest-specific protein 1 (Gas1) & 48.10 & 17.13 & -1.49 & $\begin{array}{l}5.60 \mathrm{E}- \\
116\end{array}$ \\
\hline Protein PRRC2C (Prrc2c) & 31.70 & 15.05 & -1.07 & $\begin{array}{l}1.73 \mathrm{E}- \\
153\end{array}$ \\
\hline Monofunctional C1-tetrahydrofolate synthase, mitochondrial (Mthfd1l) & 30.62 & 14.72 & -1.06 & $6.77 \mathrm{E}-53$ \\
\hline Sodium/potassium/calcium exchanger 3 (SIc24a3) & 29.19 & 14.47 & -1.01 & $7.42 \mathrm{E}-50$ \\
\hline Protein DEK (Dek) & 29.00 & 13.78 & -1.07 & 5.39E-36 \\
\hline Semaphorin-3A (Sema3a) & 27.29 & 13.47 & -1.02 & 4.21E-85 \\
\hline High mobility group protein HMGI-C (Hmga2) & 34.31 & 13.10 & -1.39 & $1.50 \mathrm{E}-35$ \\
\hline Mannose-P-dolichol utilization defect 1 protein (Mpdu1) & 25.49 & 12.73 & -1.00 & 1.24E-14 \\
\hline Lymphocyte-specific helicase (Hells) & 25.43 & 11.80 & -1.11 & 7.89E-39 \\
\hline $\begin{array}{l}\text { CKLF-like MARVEL transmembrane domain-containing protein } 3 \\
\text { (Cmtm3) }\end{array}$ & 30.93 & 11.47 & -1.43 & $5.24 \mathrm{E}-36$ \\
\hline Homeobox protein engrailed-1 (En1) & 32.58 & 11.37 & -1.52 & $1.05 \mathrm{E}-65$ \\
\hline Small subunit processome component 20 homolog (Utp20) & 27.90 & 11.06 & -1.33 & $\begin{array}{l}1.98 \mathrm{E}- \\
163\end{array}$ \\
\hline
\end{tabular}

extracellular matrix synthesis of MC3T3-E1 cells from day 7 to day 13. However, DSEH showed no significant effects on extracellular matrix synthesis of primary osteoblasts. Therefore, we further explored the molecular regulation of DSEH on the gene expression of MC3T3E1 cells using RNA-seq technique together with qRTPCR verification method, and demonstrated that DSEH promoted the proliferation of MC3T3-E1 cells and suppressed the apoptosis of those cells by regulating multiple functional genes.

According to our findings, we addressed that DSEH promoted osteoblast proliferation and extracellular matrix synthesis by increasing the expression levels of genes positively regulating the proliferation of MC3T3E1 cells, including Gstp1, Timp1, Serpine1, Cyr61, Crlf1, Thbs1, Ctgf, P4ha2, Sod3 and Nqo1. Among these genes, Gstp1 is a glutathione transferase that acts as a regulator of signaling pathways that are involved in cell proliferation, and contributes in protection against osteoblast apoptosis [26]. Timp1, a member of the tissue inhibitor of metalloproteinases family, increases osteoblast proliferation and decreased apoptosis [27]. Serpine1 is a primary inhibitor of endogenous plasminogen activators, which serves as a regulator during cell growth and cell proliferation, and plays an important role in regulating resorption during bone fracture repair [28]. Cyr61 is a cysteine-rich angiogenic inducer that is capable of regulating a broad range of cellular activities, such as cell adhesion and proliferation, and could stimulate osteoblast proliferation during bone remodeling [29]. Crlf1 is a member of the ciliary neurotrophic factor receptor pathway, and is involved in the anabolic therapy of osteoporosis through regulating osteoblast proliferation and bone formation [30]. Thbs1 is an adhesive glycoprotein that is directly deposited by bone-forming osteoblasts, and is present in the mineralized bone 

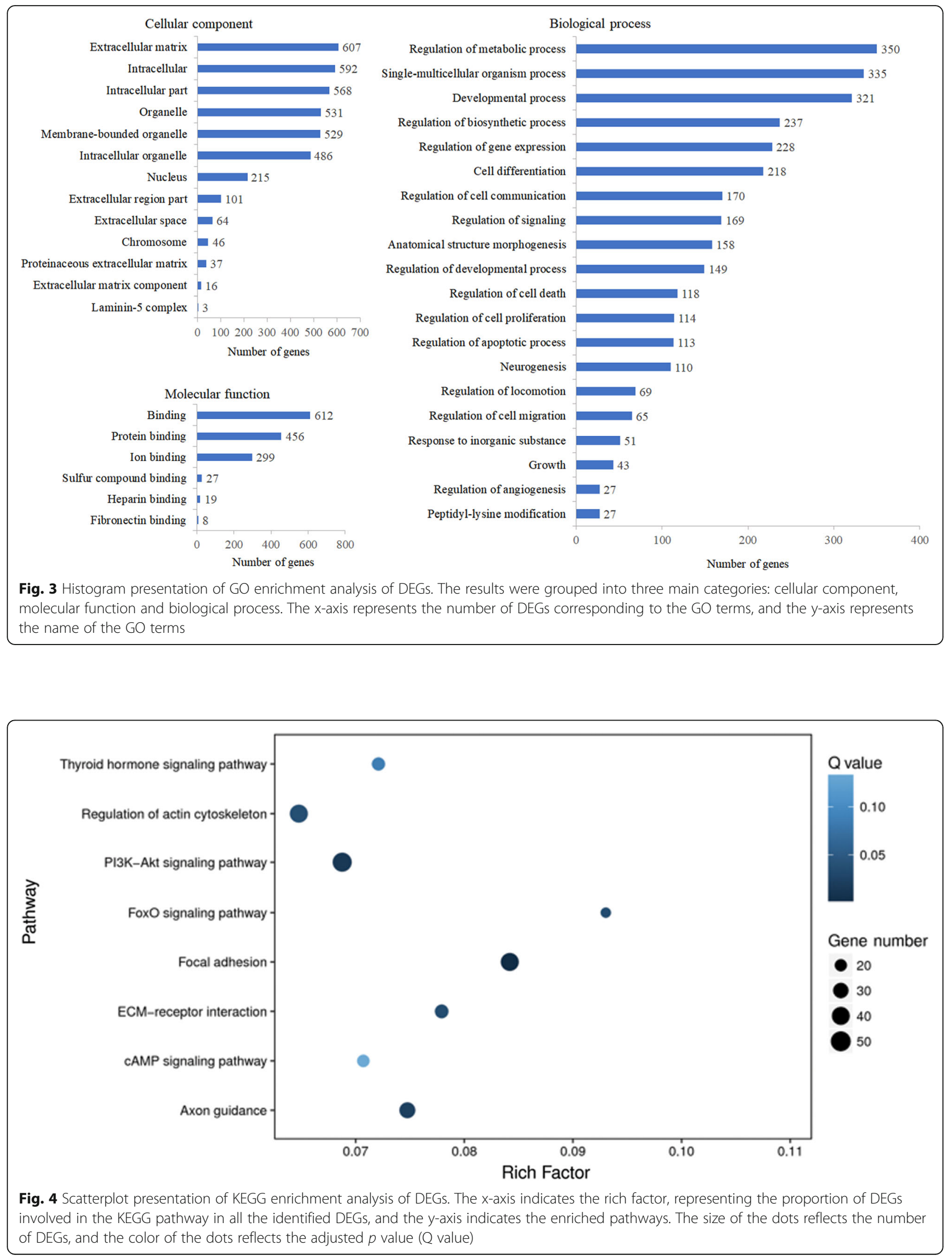
Table $\mathbf{5}$ List of DEGs positively regulating the proliferation of osteoblasts (DSEH vs. Blank)

\begin{tabular}{lllll}
\hline Gene name & Blank (FPKM) & DSEH (FPKM) & log2 fold change (DSEH/Blank) & P value \\
\hline Glutathione S-transferase P1 (Gstp1) & 367.61 & 855.07 & 1.22 & $2.30 \mathrm{E}-308$ \\
Metalloproteinase inhibitor 1 (Timp1) & 286.17 & 601.03 & 1.07 & $2.54 \mathrm{E}-223$ \\
Plasminogen activator inhibitor 1 (Serpine1) & 131.49 & 550.47 & 2.06 & 0 \\
Protein CYR61 (Cyr61) & 153.48 & 444.08 & 1.53 & 0 \\
Cytokine receptor-like factor 1 (Crlf1) & 75.46 & 270.42 & 1.84 & 0 \\
Thrombospondin-1 (Thbs1) & 94.94 & 248.54 & 1.39 & 0 \\
Connective tissue growth factor (Ctgf) & 28.09 & 357.75 & 3.67 & 0 \\
Prolyl 4-hydroxylase subunit alpha-2 (P4ha2) & 59.23 & 121.92 & 1.04 & $9.15 \mathrm{E}-124$ \\
Extracellular superoxide dismutase (Sod3) & 55.61 & 114.46 & 1.04 & $1.21 \mathrm{E}-103$ \\
NAD(P) H dehydrogenase [quinone] 1 (Nq01) & 34.57 & 107.55 & 1.64 & $1.21 \mathrm{E}-146$ \\
\hline
\end{tabular}

matrix [31]. Ctgf is an extracellular matrix-associated growth factor that plays a pivotal role in osteoblast proliferation and bone formation [32]. P4ha2 is a subunit of collagen prolyl-4-hydroxylase that is mainly expressed in osteoblasts, chondrocytes and capillary endothelial cells, and serves as an important enzyme during collagen biosynthesis [33]. Sod3 is a member of the superoxide dismutase protein family, and has a protective effect on oxidative stress-induced damage in osteoblastic cells [34]. Nqo1 is a pleiotropic enzyme that is expressed in calvarial osteoblasts, and protects the cells from oxidative damage [35]. Thus, these findings suggest that DSEH facilitate osteoblast proliferation, maintain osteoblast homeostasis and protect oxidative stress-induced damage.

We next addressed that DSEH promoted osteoblast proliferation and extracellular matrix synthesis by decreasing the expression levels of genes negatively regulating the proliferation of MC3T3-E1 cells, including Mt1, Cdc20, Gas1, Nrp2, Cmtm3, Dlk2, Sema3a, Rbm25 and Hspb6. Among these genes, Mt1 is a family member of the cysteine-rich metallothioneins, and is mainly expressed during osteoblastic differentiation and mineralization [36]. Cdc20 is an activator of the anaphase-promoting complex, and is weakly expressed in osteoblasts but highly expressed in the osteocytes [37]. Gas1 is a cell growth repressor gene that serves as a suppressive regulator of cell growth and as a mediator of apoptosis [38]. Nrp2 is a family member of the neuropilins, and one of its isoform Nrp2b inhibits cultured cell proliferation [39]. Cmtm3, a member of the chemokinelike factor gene superfamily, is an inhibitor of cell growth, and an inducer of cell apoptosis [40]. Dlk2 is a member of the EGF-like family of membrane proteins, and interacts with Notch signaling to regulate cell growth and apoptosis [41]. Sema3a is a member of the semaphoring family, which suppresses cell proliferation and promotes cell apoptosis [42]. Rbm25, a RNAbinding protein, negatively regulates cell proliferation and positively regulating cell apoptosis [43]. Hspb6, also

Table 6 List of DEGs negatively regulating the proliferation of osteoblasts (DSEH vs. Blank)

\begin{tabular}{|c|c|c|c|c|}
\hline Gene name & $\begin{array}{l}\text { Blank } \\
\text { (FPKM) }\end{array}$ & $\begin{array}{l}\text { DSEH } \\
\text { (FPKM) }\end{array}$ & $\begin{array}{l}\text { log2 fold change (DSEH/ } \\
\text { Blank) }\end{array}$ & $P$ value \\
\hline Metallothionein-1 (Mt1) & 419.48 & 188.65 & -1.15 & $\begin{array}{l}6.40 \mathrm{E}- \\
107\end{array}$ \\
\hline Cell division cycle protein 20 homolog (Cdc20) & 118.9 & 57.15 & -1.06 & 3.10E-94 \\
\hline Growth arrest-specific protein 1 (Gas1) & 48.1 & 17.13 & -1.49 & $\begin{array}{l}5.60 \mathrm{E}- \\
116\end{array}$ \\
\hline Neuropilin-2 (Nrp2) & 45.13 & 22.36 & -1.01 & $\begin{array}{l}2.48 \mathrm{E}- \\
107\end{array}$ \\
\hline $\begin{array}{l}\text { CKLF-like MARVEL transmembrane domain-containing protein } 3 \\
\text { (Cmtm3) }\end{array}$ & 30.93 & 11.47 & -1.43 & $5.24 \mathrm{E}-36$ \\
\hline Protein delta homolog 2 (Dlk2) & 29.22 & 9.04 & -1.69 & $1.81 \mathrm{E}-39$ \\
\hline Semaphorin-3A (Sema3a) & 27.29 & 13.47 & -1.02 & 4.21E-85 \\
\hline RNA-binding protein 25 (Rbm25) & 20.1 & 7.94 & -1.33 & $2.54 \mathrm{E}-57$ \\
\hline Heat shock protein beta-6 (Hspb6) & 19.42 & 8.86 & -1.13 & 2.44E-14 \\
\hline
\end{tabular}


Table 7 Gene list of osteoblast markers

\begin{tabular}{|c|c|c|c|c|}
\hline Gene name & $\begin{array}{l}\text { Blank } \\
\text { (FPKM) }\end{array}$ & $\begin{array}{l}\text { DSEH } \\
\text { (FPKM) }\end{array}$ & $\begin{array}{l}\text { log2 fold } \\
\text { change } \\
\text { (DSEH/Blank) }\end{array}$ & $\begin{array}{l}P \\
\text { value }\end{array}$ \\
\hline Osteopontin (Spp1) & 1044.05 & 2006.86 & 0.94 & 0 \\
\hline $\begin{array}{l}\text { Collagen } \\
\text { alpha-1(I) chain (Col1a1) }\end{array}$ & 1162.61 & 1354.5 & 0.22 & $\begin{array}{l}3.44 \mathrm{E}- \\
214\end{array}$ \\
\hline Fibronectin (Fn1) & 520.41 & 1033.51 & 0.99 & 0 \\
\hline $\begin{array}{l}\text { Cyclic AMP-dependent } \\
\text { transcription } \\
\text { factor ATF-4 (Atf4) }\end{array}$ & 267.17 & 322.15 & 0.27 & $\begin{array}{l}1.55 E- \\
21\end{array}$ \\
\hline $\begin{array}{l}\text { Bone marrow } \\
\text { stromal } \\
\text { antigen } 2 \text { (Bst2) }\end{array}$ & 21.42 & 28.88 & 0.43 & $\begin{array}{l}2.93 \mathrm{E}- \\
03\end{array}$ \\
\hline $\begin{array}{l}\text { Bone morphogenetic } \\
\text { protein } 1 \text { (Bmp1) }\end{array}$ & 21.89 & 26.28 & 0.26 & $\begin{array}{l}1.60 \mathrm{E}- \\
05\end{array}$ \\
\hline $\begin{array}{l}\text { Bone morphogenetic } \\
\text { protein } 4 \text { (Bmp4) }\end{array}$ & 14.42 & 17.55 & 0.28 & $\begin{array}{l}7.66 \mathrm{E}- \\
03\end{array}$ \\
\hline $\begin{array}{l}\text { Transcription } \\
\text { factor SOX-4 (Sox4) }\end{array}$ & 13.14 & 15.95 & 0.28 & $\begin{array}{l}3.01 \mathrm{E}- \\
03\end{array}$ \\
\hline $\begin{array}{l}\text { Transcription factor } \\
\text { SOX-11 (Sox11) }\end{array}$ & 5.89 & 8.68 & 0.56 & $\begin{array}{l}4.50 \mathrm{E}- \\
13\end{array}$ \\
\hline $\begin{array}{l}\text { Homeobox } \\
\text { protein MSX-1 (Msx1) }\end{array}$ & 3.28 & 5.35 & 0.71 & $\begin{array}{l}1.19 \mathrm{E}- \\
03\end{array}$ \\
\hline $\begin{array}{l}\text { Zinc finger protein } \\
25 \text { (Znf25) }\end{array}$ & 3.29 & 4.83 & 0.55 & $\begin{array}{l}2.87 \mathrm{E}- \\
04\end{array}$ \\
\hline Osteocalcin-2 (Bglap2) & 0.81 & 0.91 & 0.17 & $\begin{array}{l}8.36 \mathrm{E}- \\
01\end{array}$ \\
\hline $\begin{array}{l}\text { Transcription } \\
\text { factor Sp7 (Sp7) }\end{array}$ & 0.13 & 0.81 & 2.64 & $\begin{array}{l}1.84 \mathrm{E}- \\
04\end{array}$ \\
\hline Osteocalcin (Bglap) & 0.57 & 0.57 & 0.00 & $\begin{array}{l}9.33 \mathrm{E}- \\
01\end{array}$ \\
\hline $\begin{array}{l}\text { Dentin matrix acidic } \\
\text { phosphoprotein } 1 \text { (Dmp1) }\end{array}$ & 0.37 & 0.51 & 0.46 & $\begin{array}{l}4.05 \mathrm{E}- \\
01\end{array}$ \\
\hline $\begin{array}{l}\text { Alkaline phosphatase, } \\
\text { tissue-nonspecific } \\
\text { isozyme (Alpl) }\end{array}$ & 0.15 & 0.39 & 1.38 & $\begin{array}{l}7.43 E- \\
02\end{array}$ \\
\hline $\begin{array}{l}\text { Osteocalcin-related } \\
\text { protein (Bglap3) }\end{array}$ & 0.12 & 0.18 & 0.58 & $\begin{array}{l}7.19 \mathrm{E}- \\
01\end{array}$ \\
\hline Osteocrin (Ostn) & 0.01 & 0.09 & 3.17 & $\begin{array}{l}3.28 \mathrm{E}- \\
01\end{array}$ \\
\hline Osteomodulin (Omd) & 0.04 & 0.06 & 0.58 & $\begin{array}{l}7.19 \mathrm{E}- \\
01\end{array}$ \\
\hline $\begin{array}{l}\text { Runt-related transcription factor } \\
2 \text { (Runx2) }\end{array}$ & 11.16 & 6.42 & -0.80 & $\begin{array}{l}1.51 \mathrm{E}- \\
20\end{array}$ \\
\hline
\end{tabular}

known as Hsp20, is a small heat shock protein that participates in reducing cell proliferation and inducing cell apoptosis [44]. Thus, these findings suggest that DSEH prevent osteoblast apoptosis, maintain osteoblast homeostasis and prevent osteoblasts form further differentiation.

We further addressed that DSEH mildly increased the expression levels of a majority of the osteoblast markers, including Spp1, Col1a1, Fn1, Atf4, Bst2, Bmp1, Bmp4, Sox4, Sox11, Msx1, Znf25, Bglap2, Sp7, Bglap, Dmp1, Alpl, Bglap3, Ostn and Omd. Among these genes, Spp1, Col1a1, Fn1, Bglap, Bglap2, Bglap3 and Dmp1 are the major bone matrix protein genes [45-47]. Atf4, Sox4, Sox11, Msx1, Znf25 and Sp7 are key transcription
Table 8 List of qRT-PCR primers for DEGs

\begin{tabular}{|c|c|c|}
\hline Gene name & Primer & Sequence \\
\hline \multirow[t]{2}{*}{$\overline{\text { Gstp1 }}$} & Forward primer & ATGCCACCATACACCATTGTC \\
\hline & Reverse primer & GGGAGCTGCCCATACAGAC \\
\hline \multirow[t]{2}{*}{ Timp1 } & Forward primer & GCAACTCGGACCTGGTCATAA \\
\hline & Reverse primer & CGGCCCGTGATGAGAAACT \\
\hline \multirow[t]{2}{*}{ Serpine1 } & Forward primer & TTCAGCCCTTGCTTGCCTC \\
\hline & Reverse primer & ACACTITACTCCGAAGTCGGT \\
\hline \multirow[t]{2}{*}{ Cyr61 } & Forward primer & CTGCGCTAAACAACTCAACGA \\
\hline & Reverse primer & GCAGATCCCTITCAGAGCGG \\
\hline \multirow[t]{2}{*}{ Crlf1 } & Forward primer & CTCCCTGCAAGCTACCTGC \\
\hline & Reverse primer & AGGGTGGAGGTGTTAAGGAGG \\
\hline \multirow[t]{2}{*}{ Thbs1 } & Forward primer & GGGGAGATAACGGTGTGTTTG \\
\hline & Reverse primer & CGGGGATCAGGTTGGCATT \\
\hline \multirow[t]{2}{*}{ Mt1 } & Forward primer & GAGTCTGTAGTTGTCGCAGTTG \\
\hline & Reverse primer & GGCCTITाTGGAAGGAAGAGGA \\
\hline \multirow[t]{2}{*}{ Cdc20 } & Forward primer & TTCGTGTTCGAGAGCGATTGG \\
\hline & Reverse primer & ACCTTGGAACTAGATTTGCCAG \\
\hline \multirow[t]{2}{*}{ Gas1 } & Forward primer & CCATCTGCGAATCGGTCAAAG \\
\hline & Reverse primer & GCTCGTCGTCATATTCTTCGTC \\
\hline \multirow[t]{2}{*}{ Nrp2 } & Forward primer & GCTGGCTACATCACTTCCCC \\
\hline & Reverse primer & CAATCCACTCACAGTTCTGGTG \\
\hline \multirow[t]{2}{*}{ Cmtm3 } & Forward primer & GCCGAGTCGGGTCTITCATTC \\
\hline & Reverse primer & GAGGAAGTAAACGGCCAACAG \\
\hline \multirow[t]{2}{*}{ Dlk2 } & Forward primer & GGCCAGTGTGTGTATGACGG \\
\hline & Reverse primer & CGGCATGTGAAGTTGAGGG \\
\hline \multirow[t]{2}{*}{ Gapdh } & Forward primer & GCACAGTCAAGGCCGAGAAT \\
\hline & Reverse primer & GCCTTCTCCATGGTGGTGAA \\
\hline
\end{tabular}

factors involved in osteoblast commitment, proliferation, differentiation and extracellular matrix synthesis during bone formation [48-52]. Bst2, also known as tetherin, is a lipid raft associated protein that is highly expressed in osteoblasts, and is involved in the process of osteogenic differentiation [53]. Bmp1 and Bmp4, two members of the bone morphogenetic protein family, are important stimulator of osteoblast proliferation and differentiation, bone formation and stability [54, 55]. Alpl is a wellknown osteoblastic marker, and has been used as an evaluation indicator to estimate the capacity of bone formation [56]. Ostn is a secreted bone-active protein that is highly expressed in osteoblasts, and plays key role in regulating osteoblast activity in developing bone and at the sites of bone remodeling [57]. Omd, also known as osteoadherin, is mainly expressed in osteoblasts at early differentiated stage, and serves as an organizer of bone mineral formation [58]. However, the expression level of Runx2 was mildly decreased under DSEH treatment, and the underlying molecular mechanism still need to be further studied. Thus, these findings suggest that DSEH facilitate osteoblast proliferation, differentiation 


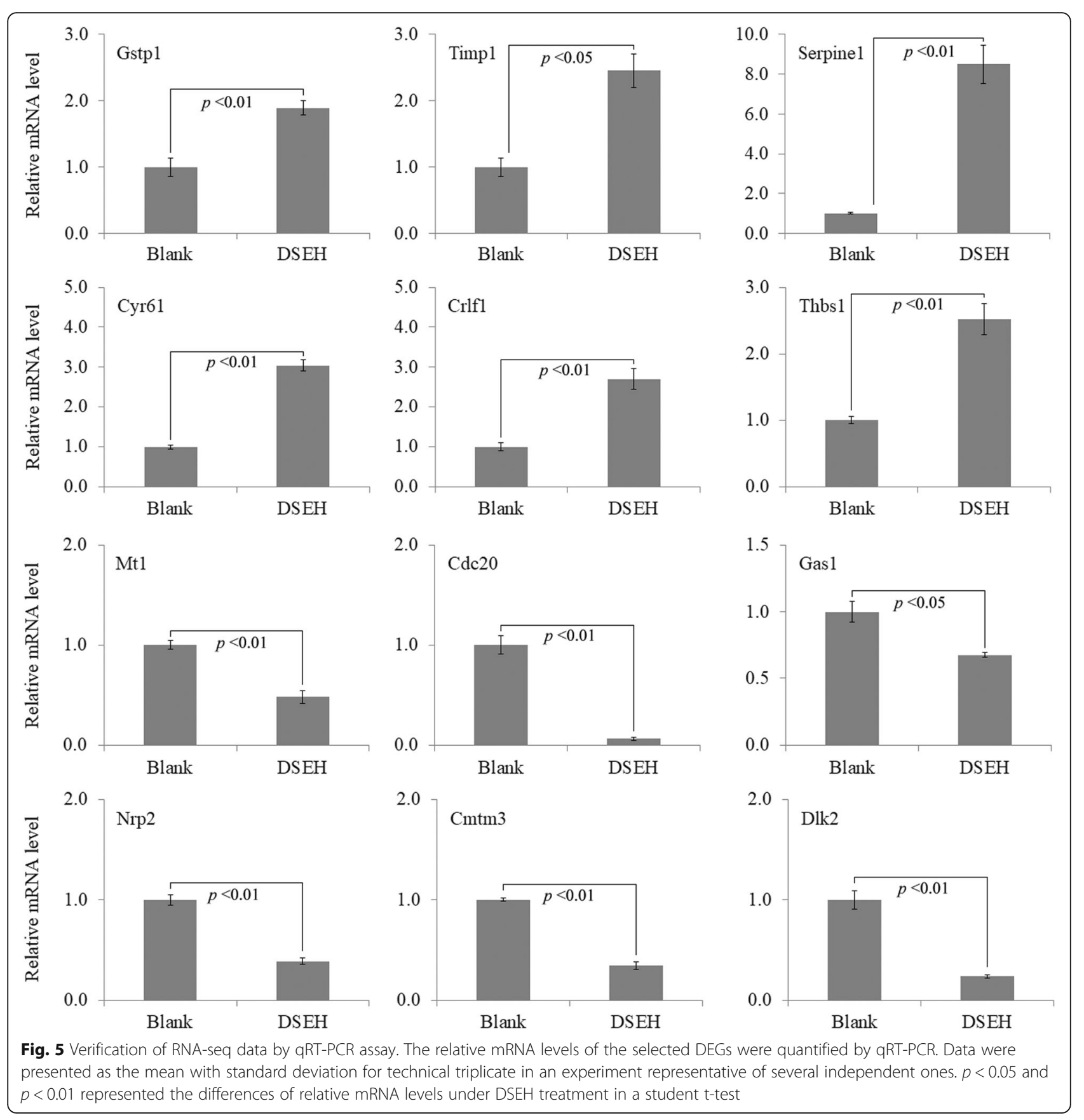

and extracellular matrix synthesis to consolidate bone formation and stability.

Consistent with the above results, our enrichment analysis of GO function and KEGG pathway indicated that the DEGs were primarily classified into the cellular components of extracellular matrix, intracellular part and organelle with dominant molecular functions of binding activities, and predominantly participated in the biological processes including regulation of metabolic process, single-multicellular organism process and developmental process. Those DEGs were mainly mapped to the signaling pathways such as thyroid hormone signaling pathway, regulation of actin cytoskeleton, PI3K-Akt signaling pathway, FoxO signaling pathway, focal adhesion, ECM-receptor interaction, cAMP signaling pathway and axon guidance. Among these pathways, thyroid hormone signaling pathway plays a key role in the regulation of bone metabolism by modulating osteoblast activity during skeletal development [59]. Actin cytoskeleton has been considered to be involved in various functions of osteoblast by discerning cell condition and regulating extracellular matrix mineralization and 


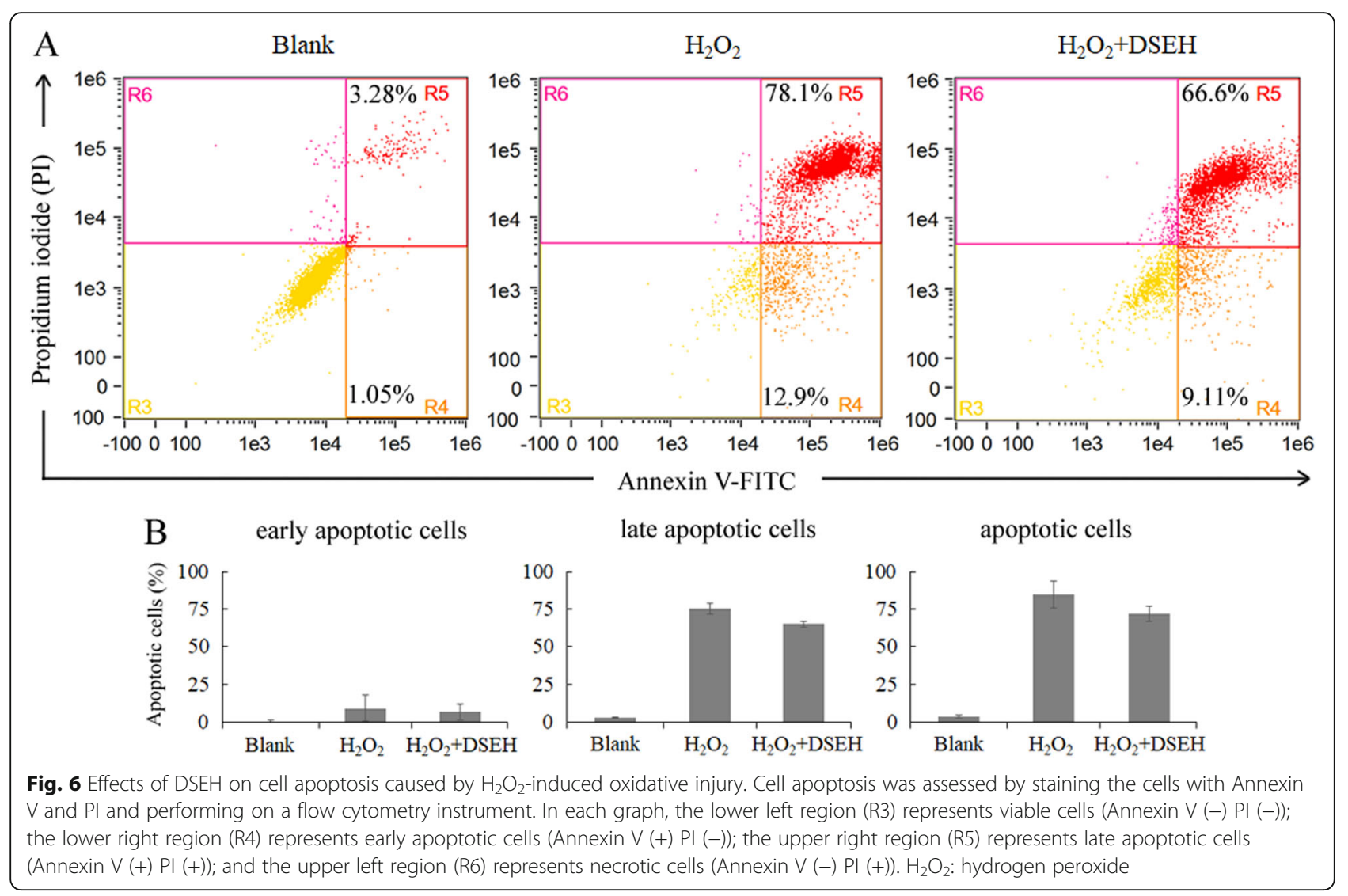

bone formation [60]. PI3K-Akt signaling pathway is a central regulation hub for osteoblast homeostasis and function, and has the capacity to work together with other signaling networks to regulate osteoblast phenotype and bone formation [61]. FoxO signaling is indispensable for bone mass homeostasis since this pathway could prevent oxidative stress and osteoblast apoptosis, and promote osteoblast proliferation to facilitate bone formation and stability [62]. Focal adhesion facilitates the perpendicular arrangement of bone matrix orthogonal to osteoblast alignment during bone formation [63]. ECM-receptor interaction plays a crucial role in regulating osteoblast adhesion, proliferation and survival during bone formation and repair [64]. cAMP signaling pathway is capable of enhancing cell adhesion of osteoblasts to facilitate bone regeneration [65]. Axon guidance signaling pathway plays a pivotal role in regulating bone formation and resorption by promoting osteoblast migration and suppressing osteoclast differentiation [66]. Finally, the results of DSEH on osteoporotic model caused by hydrogen peroxide (H2O2)-induced oxidative injury further indicated that DSEH treatment decreased the percentage of apoptotic cells, especially the late apoptotic cells. Thus, these findings confirmed that DSEH facilitated osteoblast proliferation and extracellular matrix synthesis, and prevented osteoblast oxidative stress and apoptosis to consolidate bone formation and repair.

\section{Conclusions}

In summary, we performed cell proliferation assay, Alizarin red staining and quantification, RNA-seq analysis accompanied with verification methods to dissect the molecular mechanism of DSEH in the regulation of an osteoblast-like cell line MC3T3-E1. Our findings suggest that DSEH facilitate osteoblast proliferation and extracellular matrix synthesis to consolidate bone formation and stability, but prevent osteoblasts from oxidative stress-induced damage, apoptosis and further differentiation. These findings deepened the current understanding of DSEH on regulating bone development, and provided theoretical support for the discovery of optional prevention and treatment for bone-related diseases.

\section{Abbreviations}

DSEH: Deer sinews enzymatic hydrolysate; RNA-seq: RNA sequencing; RIN: RNA integrity number; BLAST: Basic Local Alignment Search Tool; DEG: Differentially expressed genes; qRT-PCR: Quantitative real-time PCR; SRA: Sequence Read Archive; GO: Gene ontology; Gapdh: Glyceraldehyde 3phosphate dehydrogenase; KEGG: Kyoto Encyclopedia of Genes and Genomes 


\section{Acknowledgements}

Not applicable.

\section{Authors' contributions}

$\mathrm{ZZ}, \mathrm{XL}$ and $\mathrm{BY}$ conceived and designed the work; $\mathrm{XL}$ and $\mathrm{BY}$ helped to coordinate support and funding; ZZ, DZ, PZ, DP and MZ performed the experiments; $Z Z$ analyzed the data and wrote the original draft; $Z Z, X L$ and BY reviewed and revised the manuscript. All authors read and approved the final version of manuscript

\section{Funding}

This work was supported by the National Key Research and Development Program of China (Grant No. 2018YFC1706605), the TCM Clinical Research Center for Bone diseases of Jilin Province (Grant No. 20180623048TC) and the Science and Technology Development Plan Project of Jilin Province (Grant No. 20190304095YY). The funding bodies provided financial support, and the awardees performed the research. The founding sponsor had no role in the design of the study, the collection, analysis, and interpretation of data and in writing the manuscript.

\section{Availability of data and materials}

The datasets used and/or analyzed during the current study are available from the corresponding author on reasonable request.

\section{Ethics approval and consent to participate}

All procedures were submitted and approved by the ethics committee of Changchun University of Chinese Medicine in accordance with the guidelines of the ethical protocol (No. ccucm-2017-0015).

\section{Consent for publication}

Not applicable.

\section{Competing interests}

The authors declare that they have no competing interests.

\section{Author details}

${ }^{1}$ Jilin Ginseng Academy, Changchun University of Chinese Medicine, Changchun 130117, China. ${ }^{2}$ The Affiliated Hospital of Changchun University of Chinese Medicine, Changchun 130117, China. Innovation Practice Center, Changchun University of Chinese Medicine, Changchun 130117, China.

\section{Received: 17 September 2020 Accepted: 2 February 2021}

\section{Published online: 10 February 2021}

\section{References}

1. Jiang LL, Liu CL, Wong YL, Nip CF, Shaw PC. Differentiation of deer tendons from cattle tendons by a loop-mediated isothermal amplification (LAMP) test and bone remodeling bioassays. Chin Med. 2015;10:33.

2. Zhang H, Dong Y, Qi B, et al. Preventive effects of collagen peptide from deer sinew on bone loss in ovariectomized rats. Evid Based Complement Alternat Med. 2014;2014:627285.

3. Zhang H, Zhao Y, Li YQ, Sun XD, Bai XY, Zhao DQ. Effects of deer tendons collagen on osteoporosis rats induced by retinoic acid. Zhong Yao Cai. 2010;33(3):411-4.

4. Wang IL, Hsiao CY, Shen J, Wang Y, Huang CC, Chen YM. The effects of Jilin sika Deer's (Cervus dybowski) tendon liquid supplementation on endurance drop jumps performance, biochemistry profile of free boxing players. J Ethnopharmacol. 2019;245:112119.

5. Sun X, Li Y, Zhao Y, Qu Y, Zhang H, Qu X. Therapeutic effect of deer sinew collagens on rat osteoarthritis model. Zhongguo Zhong Yao Za Zhi. 2009; 23:3135-8.

6. Zhao Y, Li Y, Zhang H, Bai X, Han Y. Study on anti-inflammatory and analgesic effects of deer sinew collagens. Liaoning J Trad Chin Med. 2010; 09:1825-7

7. Sun $X$, Li Y, Zhao Y, Xing N, Bai X, Qu X. Study on the effects of antiinflammatory and immune regulation of deer sinew collagens. Lishizhen Med Mater Med Res. 2010;04:853-4

8. Thorpe CT, Screen HR. Tendon structure and composition. Adv Exp Med Biol. 2016;920:3-10.

9. Kannus P. Structure of the tendon connective tissue. Scand J Med Sci Sports. 2000;10(6):312-20.
10. Viguet-Carrin S, Garnero P, Delmas PD. The role of collagen in bone strength. Osteoporos Int. 2006;17(3):319-36.

11. Xu Z, Asakawa S. Physiological RNA dynamics in RNA-Seq analysis. Brief Bioinform. 2019;20(5):1725-33.

12. Ayturk U. RNA-seq in skeletal biology. Curr Osteoporos Rep. 2019;17(4):178-85.

13. Shapiro F. Bone development and its relation to fracture repair. The role of mesenchymal osteoblasts and surface osteoblasts. Eur Cell Mater. 2008;15:53-76.

14. Florencio-Silva R, Sasso GR, Sasso-Cerri E, Simões MJ, Cerri PS. Biology of bone tissue: structure, function, and factors that influence bone cells. Biomed Res Int. 2015;2015:421746.

15. Zhang $P$, Yao B, Leng X. Optimization of extraction conditions of collagen from deer sinew. J Agric Sci Yanbian Univ. 2020:42(1):69-75.

16. Ducy P, Starbuck M, Priemel M, Shen J, Pinero G, Geoffroy V, Amling M, Karsenty G. A Cbfa1-dependent genetic pathway controls bone formation beyond embryonic development. Genes Dev. 1999;13(8):1025-36.

17. Gregory CA, Gunn WG, Peister A, Prockop DJ. An Alizarin red-based assay of mineralization by adherent cells in culture: comparison with cetylpyridinium chloride extraction. Anal Biochem. 2004;329(1):77-84.

18. Kim D, Langmead B, Salzberg SL. HISAT: a fast spliced aligner with low memory requirements. Nat Methods. 2015;12(4):357-60.

19. Trapnell C, Williams BA, Pertea G, et al. Transcript assembly and quantification by RNA-Seq reveals unannotated transcripts and isoform switching during cell differentiation. Nat Biotechnol. 2010;28(5):511-5.

20. Altschul SF, Gish W, Miller W, Myers EW, Lipman DJ. Basic local alignment search tool. J Mol Biol. 1990;215(3):403-10.

21. Wang L, Feng Z, Wang X, Wang X, Zhang X. DEGseq: an R package for identifying differentially expressed genes from RNA-seq data. Bioinformatics. 2010;26(1):136-8.

22. Yao B, Liu J, Zhang M, Leng X, Zhao D. Deciphering the potential pharmaceutical mechanism of Guzhi Zengsheng Zhitongwan on rat bone and kidney based on the "kidney governing bone" theory. J Orthop Surg Res. 2020;15(1):146.

23. Schmittgen TD, Livak KJ. Analyzing real-time PCR data by the comparative C(T) method. Nat Protoc. 2008;3(6):1101-8.

24. Fatokun AA, Stone TW, Smith RA. Hydrogen peroxide-induced oxidative stress in MC3T3-E1 cells: the effects of glutamate and protection by purines. Bone. 2006;39(3):542-51.

25. Liu SH, Yang RS, al-Shaikh R, Lane JM. Collagen in tendon, ligament, and bone healing. A current review. Clin Orthop Relat Res. 1995;318:265-78.

26. Ragab SM, Badr EA, Ibrahim AS. Evaluation of glutathione-S-transferase P1 polymorphism and its relation to bone mineral density in Egyptian children and adolescents with beta-thalassemia major. Mediterr J Hematol Infect Dis. 2016:8(1):e2016004.

27. Merciris D, Schiltz C, Legoupil N, Marty-Morieux C, de Vernejoul MC, Geoffroy V. Over-expression of TIMP-1 in osteoblasts increases the anabolic response to PTH. Bone. 2007:40(1):75-83.

28. Rundle $\mathrm{CH}$, Wang $\mathrm{X}$, Wergedal JE, Mohan S, Lau KH. Fracture healing in mice deficient in plasminogen activator inhibitor-1. Calcif Tissue Int. 2008; 83(4):276-84.

29. Liu H, Peng F, Liu Z, et al. CYR61/CCN1 stimulates proliferation and differentiation of osteoblasts in vitro and contributes to bone remodeling in vivo in myeloma bone disease. Int J Oncol. 2017;50(2):631-9.

30. Standal T, Johnson RW, McGregor NE, et al. gp130 in late osteoblasts and osteocytes is required for PTH-induced osteoblast differentiation. J Endocrinol. 2014;223(2):181-90.

31. Amend SR, Uluckan O, Hurchla M, et al. Thrombospondin-1 regulates bone homeostasis through effects on bone matrix integrity and nitric oxide signaling in osteoclasts. J Bone Miner Res. 2015;30(1):106-15.

32. Safadi FF, Xu J, Smock SL, et al. Expression of connective tissue growth factor in bone: its role in osteoblast proliferation and differentiation in vitro and bone formation in vivo. J Cell Physiol. 2003;196(1):51-62.

33. Xiong G, Deng L, Zhu J, Rychahou PG, Xu R. Prolyl-4-hydroxylase a subunit 2 promotes breast cancer progression and metastasis by regulating collagen deposition. BMC Cancer. 2014;14:1

34. Jung WW. Protective effect of apigenin against oxidative stress-induced damage in osteoblastic cells. Int J Mol Med. 2014;33(5):1327-34.

35. Sun $Y X, X u A H$, Yang $Y$, Li J. Role of Nrf2 in bone metabolism. J Biomed Sci. 2015;22:101.

36. Dohi Y, Shimaoka H, Ikeuchi M, Ohgushi H, Yonemasu K, Minami T. Role of metallothionein isoforms in bone formation processes in rat marrow mesenchymal stem cells in culture. Biol Trace Elem Res. 2005;104(1):57-70. 
37. Billiard J, Moran RA, Whitley MZ, et al. Transcriptional profiling of human osteoblast differentiation. J Cell Biochem. 2003;89(2):389-400.

38. Dong C, Wang $X$, Li N, et al. microRNA-mediated GAS1 downregulation promotes the proliferation of synovial fibroblasts by PI3K-Akt signaling in osteoarthritis. Exp Ther Med. 2019;18(6):4273-86.

39. Gemmill RM, Nasarre P, Nair-Menon J, et al. The neuropilin 2 isoform NRP2b uniquely supports TGF $\beta$-mediated progression in lung cancer. Sci Signal. 2017;10(462):eaag0528.

40. Zhang H, Zhang J, Nan X, et al. CMTM3 inhibits cell growth and migration and predicts favorable survival in oral squamous cell carcinoma. Tumour Biol. 2015;36(10):7849-58

41. Huang Q, Li J, Zheng J, Wei A. The carcinogenic role of the notch signaling pathway in the development of hepatocellular carcinoma. J Cancer. 2019; 10(6):1570-9.

42. Capparuccia L, Tamagnone L. Semaphorin signaling in cancer cells and in cells of the tumor microenvironment--two sides of a coin. J Cell Sci. 2009; 122(Pt 11):1723-36.

43. Ge Y, Schuster MB, Pundhir S, et al. The splicing factor RBM25 controls MYC activity in acute myeloid leukemia. Nat Commun. 2019;10(1):172.

44. Nagasawa T, Matsushima-Nishiwaki R, Toyoda H, Matsuura J, Kumada T, Kozawa O. Heat shock protein 20 (HSPB6) regulates apoptosis in human hepatocellular carcinoma cells: direct association with Bax. Oncol Rep. 2014; 32(3):1291-5.

45. Komori T. Regulation of proliferation, differentiation and functions of osteoblasts by Runx2. Int J Mol Sci. 2019;20(7):1694

46. Diegel CR, Hann S, Ayturk UM, et al. An osteocalcin-deficient mouse strain without endocrine abnormalities. PLoS Genet. 2020;16(5):e1008361.

47. Lu Y, Yuan B, Qin C, et al. The biological function of DMP-1 in osteocyte maturation is mediated by its $57-\mathrm{kDa}$ C-terminal fragment. J Bone Miner Res. 2011;26(2):331-40.

48. Elefteriou F, Benson MD, Sowa $\mathrm{H}$, et al. ATF4 mediation of NF1 functions in osteoblast reveals a nutritional basis for congenital skeletal dysplasiae. Cell Metab. 2006;4(6):441-51.

49. Lefebvre V, Bhattaram P. SOXC genes and the control of skeletogenesis. Curr Osteoporos Rep. 2016;14(1):32-8.

50. Komori T. Regulation of osteoblast differentiation by transcription factors. Cell Biochem. 2006;99(5):1233-9.

51. Twine NA, Harkness L, Kassem M, Wilkins MR. Transcription factor ZNF25 is associated with osteoblast differentiation of human skeletal stem cells. BMC Genomics. 2016;17(1):872.

52. Hojo H, Ohba S, He X, Lai LP, McMahon AP. Sp7/Osterix is restricted to bone-forming vertebrates where it acts as a Dlx co-factor in osteoblast specification. Dev Cell. 2016;37(3):238-53.

53. Yoo SH, Kim JG, Kim BS, et al. BST2 mediates osteoblast differentiation via the BMP2 signaling pathway in human alveolar-derived bone marrow stromal cells. PLoS One. 2016;11(6):e0158481.

54. Asharani PV, Keupp K, Semler O, et al. Attenuated BMP1 function compromises osteogenesis, leading to bone fragility in humans and zebrafish. Am J Hum Genet. 2012;90(4):661-74.

55. Chang SF, Chang TK, Peng HH, et al. BMP-4 induction of arrest and differentiation of osteoblast-like cells via p21 CIP1 and p27 KIP1 regulation. Mol Endocrinol. 2009;23(11):1827-38.

56. Liu W, Zhang L, Xuan K, et al. Alpl prevents bone ageing sensitivity by specifically regulating senescence and differentiation in mesenchymal stem cells. Bone Res. 2018;6:27.

57. Bord S, Ireland DC, Moffatt P, Thomas GP, Compston JE. Characterization of osteocrin expression in human bone. J Histochem Cytochem. 2005;53(10): $1181-7$.

58. Rehn AP, Chalk AM, Wendel M. Differential regulation of osteoadherin (OSAD) by TGF-beta1 and BMP-2. Biochem Biophys Res Commun. 2006; 349(3):1057-64.

59. Kim HY, Mohan S. Role and mechanisms of actions of thyroid hormone on the skeletal development. Bone Res. 2013;1(2):146-61.

60. Suzuki H, Tatei K, Ohshima N, Sato S, Izumi T. Regulation of MC3T3-E1 differentiation by actin cytoskeleton through lipid mediators reflecting the cell differentiation stage. Biochem Biophys Res Commun. 2019;514(2):393400.

61. McGonnell IM, Grigoriadis AE, Lam EW, Price JS, Sunters A. A specific role for phosphoinositide 3-kinase and AKT in osteoblasts? Front Endocrinol (Lausanne). 2012;3:88.
62. Ambrogini E, Almeida M, Martin-Millan M, et al. FoxO-mediated defense against oxidative stress in osteoblasts is indispensable for skeletal homeostasis in mice. Cell Metab. 2010;11(2):136-46.

63. Nakanishi Y, Matsugaki A, Kawahara K, Ninomiya T, Sawada H, Nakano T. Unique arrangement of bone matrix orthogonal to osteoblast alignment controlled by Tspan11-mediated focal adhesion assembly. Biomaterials. 2019;209:103-10.

64. Shekaran A, García AJ. Extracellular matrix-mimetic adhesive biomaterials for bone repair. J Biomed Mater Res A. 2011;96(1):261-72.

65. Lo KW, Ashe KM, Kan HM, Lee DA, Laurencin CT. Activation of cyclic amp/ protein kinase: a signaling pathway enhances osteoblast cell adhesion on biomaterials for regenerative engineering. J Orthop Res. 2011;29(4):602-8.

66. Iqbal J, Yuen T, Kim SM, Zaidi M. Opening windows for bone remodeling through a SLIT. J Clin Invest. 2018;128(4):1255-7.

\section{Publisher's Note}

Springer Nature remains neutral with regard to jurisdictional claims in published maps and institutional affiliations.
Ready to submit your research? Choose BMC and benefit from:

- fast, convenient online submission

- thorough peer review by experienced researchers in your field

- rapid publication on acceptance

- support for research data, including large and complex data types

- gold Open Access which fosters wider collaboration and increased citations

- maximum visibility for your research: over $100 \mathrm{M}$ website views per year

At BMC, research is always in progress.

Learn more biomedcentral.com/submissions 